\title{
Bank Acquisition Announcements And Intra-Industry Effects
}

Yvette M. Bendeck, (E-mail: bendeck@uhcl.edu), University of Houston-Clear Lake Edward R. Waller, (E-mail: waller@uhcl.edu), University of Houston-Clear Lake

\begin{abstract}
In this paper we attempt to assess whether gains in wealth associated with bank consolidation are the result of economic efficiencies by analyzing effects of bank merger announcements on the values of bidders, targets, and rival banks in the target's geographical area. We find target banks earn positive returns, while bidding banks sustain negative returns at acquisition announcement. These findings are consistent with previously reported results in the bank consolidation literature. We also find rival banks earn positive returns that are enhanced when the target bank is in distress. We suggest the results are consistent with the view that investors interpret acquisition announcements as positive, geographically specific signals that may, in turn, reflect event-specific or bank-specific characteristics rather than expectations of increased efficiencies.
\end{abstract}

\section{INTRODUCTION}

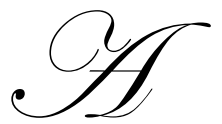

common explanation for expecting positive returns to bank mergers is the potential for consolidations to generate economic efficiencies. In particular, practitioner discussions often cite economies of scale in management functions such as marketing, planning, and administration as the rationale for bank merger wealth gains. From this perspective, bank mergers more efficiently reallocate resources due to administrative efficiencies such as back-office consolidation and improvements in managerial quality, as well as gains from the elimination of redundant branches if the banks already operate in the same market. In effect, the efficiency argument predicts that a control transaction transfers assets from a target bank to an acquiring bank that can more efficiently utilize and manage the target's assets. From this perspective, bank mergers permit the bidder to seize economies of scale and scope. Mergers that generate synergies strengthen the efficiency and competitiveness of the consolidating banks that gain at the expense of rival banks.

Mergers can also provide valuable opportunities for geographical diversification. Although shareholders can diversify their portfolios to obtain geographical balance, an acquiring bank may benefit from access to new markets that improve the profitability of current operations that have been previously geographically constrained.

The asset services view of intermediation originally developed by Diamond (1984), Ramakrishnan and Thakor (1984), and Fama (1985) view the gathering and processing of private information as central to banking activity. From this perspective, loan customers develop relationships with banks that foster the transfer of confidential information. There is a natural monopoly aspect to these information processing activities so benefits can accrue from bank mergers. Larger bank size and broader geographical coverage imply a smaller probability a firm will outgrow its banking relationship. Increased bank size enhances specialization in the processing of private information, which implies more efficient sorting of borrowers due to reduced marginal costs in evaluating new and continuing loan clients. Clients with favorable private information will prefer to deal with an informationally efficient bank as a source of external financing rather than utilize the public securities market which is more likely to classify the borrower as having above average risk, requiring an appropriately higher cost of capital, because of information asymmetry-induced adverse selection bias. The asset services view of intermediation, in contrast to firm use of public securities markets, suggests there are returns to scale in banking because banks' credit portfolios become more diversified and profits more deterministic as bank size increases, so an increase in scale should be a source of gains from merger activity. 
However, empirical cost analyses of bank consolidations have historically suggested that economies of scale are weak and average costs are flat. For example, Srinivasan (1992) reported that declines in operating costs for merged banks parallel those of the banking industry, while Berger and Humphrey (1992) and Cornett and Tehranian (1992) reported evidence of post-merger cost efficiencies. Hunter and Timme (1989) found no evidence for economies of scope in banking and Gorton and Rosen (1995) indicated that mergers do not reduce excess lending capacity. In a review of the bank merger and cost efficiency literature, Berger et al. (1999) report little or no cost efficiency improvement from bank consolidations.

The gains in efficiency from bank mergers and acquisitions may also be assessed by examining the effects of bank merger announcements on the values of bidders, targets, and rival banks located within the target's geographical area. Specifically, since gains in bank efficiency that are expected to result from an acquisition should be capitalized and reflected in market price responses to acquisition announcements, an analysis of share prices provides an opportunity to assess whether there are productive gains from bank mergers. If a bank merger generates gains in productive efficiency for the consolidated entity that trigger a reallocation of future cash flows away from rival banks, share prices of rivals should fall in response to news of the acquisition.

Previous studies of bank acquisitions, such as Rosen (2006), DeLong (2001), Houston et al. (2001), Becher (2000), Akhigbe and Madura (1999), Houston and Ryngaert (1994), Cornett and Tehranian (1992), Cornett and De (1991), and James and Wier (1987), use stock market data to document that bank mergers generate large gains in wealth for shareholders of target banks, but the benefits of acquisitions for acquiring banks are less clear, given the ambiguous pattern of share-price effects on acquirers reported in these studies. More recently, DeLong and DeYoung (2007) suggest that academic studies reject the hypothesis that bank acquisitions create value because investors are unable to accurately assess the value of bank acquisitions when regulations, technologies, industry structure, and merger profiles are changing rapidly.

Moreover, DeLong (2001) shows bank mergers that enhance value at announcement can be distinguished from those mergers that do not by classifying mergers according to activity and similarity and then examining the abnormal returns to each group as a result of merger announcement. She finds that mergers that focus both activity and geography enhance stockholder value while other types of mergers do not create value. Her analysis also suggests that announcement returns are increasing in relative size of target to bidder, but decreasing in pre-announcement performance of targets.

Akhigbe and Madura (1999) attempt to determine whether bank acquisition announcements transmit intra-industry signals, explain why intra-industry effects vary across acquisition announcements, and explain why valuation effects of individual rival banks vary. They find, on average, bank acquisition announcements generate significant positive intraindustry effects. Moreover, they find the valuation effects of rival bank portfolios are positively related to the valuation effects of target banks, and inversely related to the size and prior performance of rival bank portfolios. They also suggest valuation effects are more favorable for individual rival banks that are ultimately acquired. In effect, Akhigbe and Madura suggest bank acquisitions transmit a signal about the banking industry and the strength of the signal is influenced by eventspecific and rival bank-specific characteristics.

In this paper, we attempt to assess the effects of bank mergers on market values of bidders and targets, as well as of rivals, which, like DeLong (2001), we define as banks located in the same geographical area as the target bank. This approach may allow us to evaluate the information effects of bank mergers and to gain perspective on the sources of economic gains or losses associated with bank consolidation.

Specifically, we examine share-price responses to acquisition announcements for target banks, bidding banks, and rivals of target banks. Several results emerge from our study. We find that there are positive excess returns for target banks. For bidding banks, excess returns at merger announcements are negative. Like Akhigbe and Madura (1999), we find significant positive information effects at acquisition announcements for banks that are rivals of target banks. We also find that returns to rivals are significantly more favorable at bids for distressed targets than for non-distressed targets. Since intra-industry effects are positive and directly related to the existence of target bank financial distress, we suggest the results may reflect announcement release of positive, geographically specific industry information, rather than expectations of increased efficiencies. 
The remainder of the paper is organized as follows. Data and methodology are described next. Then, we report our empirical evidence, followed by our conclusions.

\section{SAMPLE AND METHODOLOGY}

The sample of bank acquisitions is obtained from several sources, including Mergers and Acquisitions, the Federal Reserve Bulletin, and the American Banker. The sample consists of acquisitions involving publicly traded bank holding companies between 1980 and 1996 so that our sample period and results are comparable with Akhigbe and Madura (1999) and DeLong (2001). Each merger requires the approval of the Federal Reserve Board before the consolidation can be consummated. Information is obtained about the identity of other publicly traded rival banks that operate in a deposit market of the target bank. The two major criteria for retention of a merger in the sample are that one, the target and/or bidder, and rival banks must have sufficient daily stock price data on the Center for Research in Securities Prices (CRSP) NYSE, AMEX or NASDAQ files to allow estimation of an event study model and, two, the relevant Federal Reserve staff report on the merger must be available. We exclude acquisitions in which there are multiple bidders since share price responses for targets, bidders, and rivals in response to news of such events can be expected to reflect expectations about the probability that a bidding contest will develop and the impact of activities conducted by competing bidders, in addition to capitalizing the anticipated effects of the original acquisition bid. Regulatory sales and auctions of failed banks are also excluded. Our final sample of publicly traded bidders consists of 153 banks; the final sample of publicly traded targets consists of 95 banks. There are 148 merger events for which there are one or more publicly traded rivals of the target bank.

Information about the samples of banks and transaction characteristics are collected from Wall Street Journal articles, Standard and Poor's Bank Manuals, Mergent Online, and the American Banker. In addition, we are able to identify whether the target bank was in financial distress at the time of acquisition bid.

Excess returns are calculated using the market model over a 120 day period, days $\quad-250$ to -131 , prior to each announcement, day 0 . We report cumulative excess returns during two-day and five-day announcement windows for target and bidding banks. In the case of rival banks, for each event we pool (that is, average) excess returns for all relevant rivals, and then we average the pooled returns over all events each day and cumulate these returns over the relevant announcement window. This procedure for generating rival excess returns follows the procedure used in Lang and Stulz (1992) and Slovin et al. (1991). The null hypothesis of the statistical test is that the average excess return equals zero. The test statistic, reported in parentheses in the tables below the relevant return, is the ratio of the relevant average excess return to its estimated standard deviation obtained from the time series of excess returns during the 120 day pre-event estimation period (-250 to -131$)$.

\section{EMPIRICAL RESULTS}

\section{Market Reaction For Target Banks}

Excess returns for banks that are targets of acquisition bids are reported in Table 1. In Panel A, for the full sample of 95 target banks, the two-day average excess return is $11.89 \%$ with a t-statistic of 40.87 . There is a significant positive excess return on day -1 as well as on day 0 . The five-day excess return is $11.41 \%$ (t-statistic of 24.80 ) so the magnitude of the returns just prior to the announcement is trivial compared to the two-day announcement window. For the preannouncement period $-15,-2$, the cumulative average excess return is $6.41 \%$ with a t-statistic of 8.32 , significant at the $1 \%$ confidence level. These results indicate that the market anticipates bank acquisition announcements for target banks but this anticipation is only partial since the actual announcement generates a large positive effect on target bank share price. There is a small, and not statistically significant, return for the post-announcement period, +1 to +15 . (Post-event returns are not reported in the tables). 


\section{Market Reaction For Bidder Banks}

Average excess returns for bidder banks are reported in Table 2. In Panel A, for the full sample of 153 acquisition bids, the two-day average excess return to bidders is $-1.28 \%$ (t-statistic of -7.42 ). The five-day excess return is $-0.72 \%$ (tstatistic of -2.64) so the magnitude of returns just prior to the announcement is small compared to the two-day window. For the pre-announcement period, $-15,-2$, the cumulative average excess return is $0.57 \%$ with a t-statistic of 1.24 , which is not statistically significant. These results indicate there is a negative return to acquirers in response to acquisition announcements and the market does not anticipate the identity of bidding banks prior to announcement. The excess returns to bank acquirers are consistent with the negative and significant returns for acquirers of financial firms reported by DeLong (2001) (-1.68\%) and for acquirers of nonfinancial firms reported by Byrd and Hickman (1992) (-1.20\%), Bradley, Desai and Kim (1988) (-2.90\%), Servaes (1991) (-3.3\%), Varaiya and Ferris (1987) (-2.15\%), and Jennings and Mazzeo (1991) $(-0.80 \%)$, and may be suggestive of overbidding.

Table 1

\section{Excess Returns For Target Banks}

Average prediction errors ${ }^{\mathrm{a}}$ in percentage terms for banks that are targets of acquisition bids announced over the period 1980 through 1996, and are traded on the New York or American Stock Exchange or NASDAQ; (t-statistics in parentheses ${ }^{\mathrm{b}}$, proportion of positive returns in brackets).

\begin{tabular}{ccc}
\hline $\begin{array}{c}\text { Two-day return } \\
(-1,0)\end{array}$ & $\begin{array}{c}\text { Five-day return } \\
(-4,0)\end{array}$ & $\begin{array}{c}\text { Pre-event period return } \\
(-15,-2)\end{array}$ \\
\hline \multicolumn{2}{c}{ Panel A: Full sample N=95 } \\
\hline 11.89 & 11.41 & 6.41 \\
$(40.87)^{* *}$ & $(24.80)^{* *}$ & $(8.32)^{* *}$ \\
& & \\
\hline
\end{tabular}

a Prediction errors are calculated as the difference between realized returns and expected returns obtained from a least squares regression estimated over the pre-event period -250 to -131 , where day $\mathrm{t}=0$ is the date of first announcement.

b Statistical significance is indicated by:

*Significant at the 5\% confidence level

**Significant at the $1 \%$ confidence level

Table 2

Excess Returns For Bidder Banks

Average prediction errors ${ }^{\mathrm{a}}$ in percentage terms for banks that are bidders in acquisition bids announced over the period 1980 through 1996, and are traded on the New York or American Stock Exchange or NASDAQ; (t-statistics in parentheses ${ }^{\mathrm{b}}$, proportion of positive returns in brackets).

\begin{tabular}{ccc}
\hline $\begin{array}{c}\text { Two-day return } \\
(-1,0)\end{array}$ & $\begin{array}{c}\text { Five-day return } \\
(-4,0)\end{array}$ & $\begin{array}{c}\text { Pre-event period return } \\
(-15,-2)\end{array}$ \\
\hline \multicolumn{2}{c|}{ Panel A: Full sample N=153 } & 0.57 \\
\hline-1.28 & -0.72 & $(1.24)$ \\
& $(-2.64)^{* *}$ & \\
\hline
\end{tabular}

a Prediction errors are calculated as the difference between realized returns and expected returns obtained from a least squares regression estimated over the pre-event period -250 to -131 , where day $\mathrm{t}=0$ is the date of first announcement.

b Statistical significance is indicated by:

*Significant at the $5 \%$ confidence level

**Significant at the $1 \%$ confidence level 
Table 3

\section{Excess Returns For Geographical Rival Banks}

Average prediction errors ${ }^{\mathrm{a}}$ in percentage terms for banks that are rivals of banks that are targets of acquisition bids announced over the period 1980 through 1996, and are traded on the New York or American Stock Exchange or NASDAQ; (t-statistics in parentheses ${ }^{\mathrm{b}}$, proportion of positive returns in brackets).

\begin{tabular}{|c|c|c|c|}
\hline & $\begin{array}{c}\text { Two-day return } \\
(-1,0)\end{array}$ & $\begin{array}{c}\text { Five-day return } \\
(-4,0)\end{array}$ & $\begin{array}{c}\text { Pre-event period return } \\
(-15,-2)\end{array}$ \\
\hline \multicolumn{4}{|c|}{ Panel A: Full sample $\mathrm{N}=148$} \\
\hline & $\begin{array}{c}1.06 \\
(8.42)^{* *} \\
{[0.55]}\end{array}$ & $\begin{array}{c}0.96 \\
(4.83)^{* *}\end{array}$ & $\begin{array}{c}-0.03 \\
(\square-0.73)\end{array}$ \\
\hline \multicolumn{4}{|c|}{ Panel B: By distress status of target bank } \\
\hline $\begin{array}{l}\text { No distress } \\
\mathrm{N}=132\end{array}$ & $\begin{array}{c}0.88 \\
(6.66)^{* *} \\
{[0.52]}\end{array}$ & $\begin{array}{c}0.63 \\
(3.02)^{* *}\end{array}$ & $\begin{array}{c}0.29 \\
(\square 0.84)\end{array}$ \\
\hline $\begin{array}{l}\text { Distressed target } \\
\mathrm{N}=16\end{array}$ & $\begin{array}{c}2.52 \\
(5.52)^{* *} \\
{[0.75]}\end{array}$ & $\begin{array}{c}3.76 \\
(5.52)^{* *}\end{array}$ & $\begin{array}{c}0.55 \\
(0.48)\end{array}$ \\
\hline
\end{tabular}

a Prediction errors are calculated as the difference between realized returns and expected returns obtained from a least squares regression estimated over the pre-event period -250 to -131 , where day $\mathrm{t}=0$ is the date of first announcement. Rival banks are grouped into portfolios by event as described in Section 3.

b Statistical significance is indicated by:

*Significant at the $5 \%$ confidence level

** Significant at the $1 \%$ confidence level

\section{Intra-Industry Effects}

As reported in Panel A of Table 3 for 148 bank acquisition announcements, the two-day average excess return for portfolios of rival banks, that is banks that operate in the deposit markets of the target, is $1.06 \%$ with a t-statistic of 8.42 , significant at the $1 \%$ level. The five-day excess return is similar, $0.96 \%$, with a t-statistic of 4.83 , significant at the $1 \%$ level. For the pre-announcement period $-15,-2$, the cumulative average excess return is $0.03 \%$ with a t-statistic of -0.73 . The results indicate that merger announcements generate significantly positive effects on the share prices of rival banks.

In Panel B, we disaggregate the sample into announcements of acquisition bids based on whether or not the target bank is in financial distress. Financial distress is determined by published evidence of dividend reductions, negative regulatory announcements, or other deleterious news prior to the merger announcement. We identify 16 target banks in the sample that are in distress at the time of the acquisition announcement. The two-day average excess return for rival banks in response to bids for 132 target banks not in financial distress is $0.88 \%$ (t-statistic of 6.66) compared to $2.52 \%$ (t-statistic of 5.52) for rivals of 16 target banks in financial distress. A difference in means test between these two figures yields a calculated $t$-value of 2.20 , which rejects equality of the returns. The excess returns for the five-day interval are $0.63 \%$ ( $t-$ statistic of 3.02) for the non-distress group versus $3.76 \%$ (t-statistic of 5.52) for the distress group. The calculated t-value for a difference in means test for these two figures is 3.18, significant at the $1 \%$ confidence level, also rejecting the null hypothesis of equality between the share price response of rivals to acquisition announcements involving distressed versus non-distressed target banks.

Although, unlike DeLong (2001), we find the stock price reactions for bidders and targets at acquisition bids for distressed banks are similar to the stock price reactions observed when target banks are not in distress, we also find that the return to rival banks is more positive when the target of the bid is in distress than when the target is not in distress. We suggest these results may imply the onset of financial distress at a bank has a negative, contagion-type effect on the value of 
banks in the same geographical area rather than a positive competitive effect on rivals. Consequently, a merger that incorporates a bank that is in distress into a bidding bank may convey positive information about the values of rival banks in the same area as the target bank.

Akhigbe and Madura (1999) suggest that investors use both event-specific characteristics and rival bank-specific characteristics when valuing rival banks at acquisition announcement. An interpretation of their results is either that acquisition announcements are signaling individual event-specific or rival bank-specific characteristics, or that acquisition announcements are interpreted by investors as positive, geographically specific signals that are, in turn, affected by eventspecific or rival bank-specific characteristics. Regardless, the event-specific or rival bank-specific information should be suggestive of increased efficiencies only if acquisition announcement conveyed positive information about geographicallyspecific rivals. Thus, we interpret the significant positive announcement returns for rivals as suggestive of positive, geographically specific industry information rather than expectations of increased efficiencies.

Our results, taken as a whole, suggest a merger that incorporates a bank that is in distress into a bidding bank conveys positive information about the values of rival banks in the same area as the target bank. The implication is that that the positive gains to rival banks are due to positive private information conveyed by the bid about target bank value and that the information is viewed as having geographically common elements. Since merger bids entail the expenditure of considerable resources by bidders in researching potential acquisition targets, our results indicate that shareholders of rivals of target banks obtain significant benefits from the information gathering activities of bidders. In this sense, our results are consistent with Akhigbe and Madura in that acquisition announcements are interpreted by investors as positive, geographically specific signals that are, in turn, affected by event-specific or bank-specific characteristics. A plausible alternative is that relevant event-specific or bank-specific characteristics may reflect increased efficiencies. However, positive rival returns are inconsistent with this view.

\section{CONCLUSIONS}

This paper attempts to provide evidence about the share price effects of bank mergers and analyzes whether wealth gains in response to these consolidations reflect increases in economic efficiencies. We find that target banks earn large positive excess returns, but bidding banks sustain negative returns in response to acquisition bids. Since rival banks earn positive returns in response to bank acquisition announcements that are enhanced when the target is distressed, we suggest the evidence is consistent with the view that markets returns reflect positive, geographically-specific information rather than expectations of increased efficiencies.

Our paper may have important implications for federal bank regulatory policy. Federal bank regulators and the Department of Justice have responsibility for enforcing antitrust statutes in the banking industry and have broad authority to evaluate the competitive effects of bank mergers in determining whether to approve a merger. Various components of the guidelines established by these agencies incorporate changes in market concentration induced by a proposed consolidation, assessments as to whether competitive conditions are conducive to market power, the prevalence of barriers to entry, and whether a merger may generate important efficiency gains that would benefit customers through lower prices or improved service. Supporters of consolidation argue that mergers lead to strong, diversified banks that are able to compete more effectively. However, the results of our study may also imply that gains in wealth from bank consolidation are not the result of increases in economic efficiencies at the level of individual banks, but rather may reflect positive, geographically specific industry information. 


\section{REFERENCES}

1. Akhigbe, A., and J. Madura, 1999. Intra-industry signals embedded in bank acquisition announcements. Journal of Banking and Finance 23: 1637-1654.

2. $\quad$ Becher, D., 2000. The valuation effects of bank mergers. Journal of Corporate Finance 6: 189-214.

3. Berger, A., and D. Humphrey, 1992. Mega-mergers in banking and the use of cost efficiency as an antitrust defense. The Antitrust Bulletin 33.

4. Berger, A., R. Demsetz, and P. Strahan, 1999. The consolidation of the financial services industry: Causes, consequences, and implications for the future. Journal of Banking and Finance 23: 135-194.

5. Bradley, M., A. Desai, and E. Kim, 1988. Synergistic gains from corporate acquisitions and their division between

6. the stockholders of target and acquiring firms. Journal of Financial Economics 21: 3-40.

7. Byrd, J., and K. Hickman, 1992. Do outside directors monitor managers? Evidence form tender offers. Journal of Financial Economics 32: 195-222.

8. Cornett, M., and S. De, 1991. Common stock returns in corporate takeover bids: Evidence from interstate bank mergers. Journal of Banking and Finance 15: 273-295.

9. Cornett, M., and H. Tehranian, 1992. Changes in corporate performance associated with bank acquisitions. Journal of Financial Economics 31: 211-234.

10. DeLong, G., 2001. Stockholder gains from focusing versus diversifying bank mergers. Journal of Financial Economics 59: 221-252.

11. DeLong, G., and R. DeYoung, 2007. Learning by observing: Information spillovers in the execution and valuation of commercial bank M\&As. Journal of Finance 62: 181-216.

12. Diamond, D., 1984. Financial intermediation and delegated monitoring. Review of Financial Studies 52: 393414.

13. Fama, E., 1985. What's different about banks? Journal of Monetary Economics 15: 29-39.

14. Gorton, G., and R. Rosen, 1995. Corporate control, portfolio choice, and the decline of banking. Journal of Finance 50: 1377-1420.

15. Houston, J., and M. Ryngaert, 1994. The overall gains from large bank mergers. Journal of Banking and Finance 18: 1155-1176.

16. Houston, J., C. James, and M. Ryngaert, 2001. Where do merger gains come from? Bank mergers from the perspective of insiders and outsiders. Journal of Financial Economics 60: 285-331.

17. Hunter, W., and S. Timme, 1989. Does multi-product production in large banks reduce costs? Federal Reserve Bank of Atlanta Business Review, 2-11.

18. James, C., and P. Wier, 1987. An analysis of FDIC failed bank auctions. Journal of Monetary Economics 20: 141-153.

19. Jennings, R., and M. Mazzeo, 1991. Stock price movements around acquisition around acquisition announcements and management's response. Journal of Business 64: 139-164.

20. Lang, L., and R. Stulz, 1992. Contagion and competitive intra-industry effects of bankruptcy announcements. Journal of Financial Economics 32: 45-60.

21. Ramakrishnan, R., and A. Thakor, 1984. Information reliability and a theory of financial intermediation. Review of Financial Studies 52: 415-432.

22. Rosen, R., 2006. Merger momentum and investor sentiment: The stock market reaction to merger announcements. Journal of Business 79: 987-1017.

23. Servaes, H., 1991. Tobin's Q and the gains from takeovers. Journal of Finance 46: 409-426.

24. Slovin, M., Sushka, M., and Y. Bendeck, 1991. The intra-industry effects of going private. Journal of Finance 46: 1537-1550.

25. Srinivasan, A., 1992. Are there cost savings from bank mergers? Federal Reserve Bank of Atlanta Economic Review, 17-28.

26. Varaiya, N. Ferris, K., 1987. Overpaying in corporate takeovers: The winner's curse. Financial Analysts Journal 43: 64-71. 


\section{NOTES}

